\title{
COVID-19 Pandemisinin İnsan Kaynakları Yönetimi Üzerine Etkilerinin Belirlenmesine Yönelik Bir Araştırma
}

Selma KILIÇ-KIRILMAZ (https://orcid.org/0000-0002-8478-1910), Sakarya University of Applied Sciences, Turkey; skirilmaz@subu.edu.tr

\section{A Research to Determine the Effects of COVID-19 Pandemic on Human Resources Management}

\begin{abstract}
This research aims to determine the effects of the COVID-19 Pandemic on human resource management practices. Research data were collected from the Human Resources Managers (HRM) of the enterprises using a questionnaire. Within the scope of the research, 240 questionnaires were collected, and the analyses were carried out on these questionnaires. Hypotheses were tested using Chi-Square analysis. As a result of the research, it was found that the COVID-19 Pandemic caused changes in the transition of enterprises to remote or flexible working models, employee procurement and selection, training, performance management, career management, and motivation practices. It is thought that the research results will make an important contribution to both the literature and businesses.

Keywords $\quad$ : Human Resources Management (HRM), COVID-19, Pandemic.

JEL Classification Codes: $\quad$ M12, M54.

\section{Öz}

$\mathrm{Bu}$ araştırmanın amacı; COVID-19 Pandemisinin insan kaynakları yönetimi uygulamalarına olan etkilerinin belirlenmesidir. Araştırma verileri işletmelerin İnsan Kaynakları Yöneticilerinden (IKKY) anket yolu ile toplanmıştır. Araştırma kapsamında 240 adet anket toplanmış ve analizler bu anketler üzerinden gerçekleştirilmiştir. Hipotezler Ki-Kare analizinden yararlanılarak test edilmiştir. Araştırma sonucunda COVID-19 Pandemisinin işletmelerin uzaktan veya esnek çalışma modeline geçmelerinde, çalışan tedarik ve seçiminde, eğitim, performans yönetimi, kariyer yönetimi ve motivasyon uygulamalarında değişikliklere neden olduğu bulunmuştur. Araştırma sonuçlarının hem literatüre hem de işletmelere önemli bir katkı sağlayacağı düşünülmektedir.
\end{abstract}

Anahtar Sözcükler : İnsan Kaynakları Yönetimi (IKKY), COVID-19, Pandemi. 
Kılıç-Kırılmaz, S. (2021), "COVID-19 Pandemisinin İnsan Kaynakları Yönetimi Üzerine Etkilerinin Belirlenmesine Yönelik Bir Araştırma”, Sosyoekonomi, 29(50), 255-276.

\section{Giriş}

COVID-19 Pandemisi, Aralık 2019'da Çin'in Hubei bölgesi başkenti Wuhan'da başladıktan kısa bir süre sonra tüm dünyaya yayılmıştır ve 11 Mart 2020’de Dünya Sağlık Örgütü tarafından bu salgın Pandemi olarak ilan edilmiştir (WHO, 2020). COVID-19 Pandemisi tüm toplumu, çalışanları ve işletmeleri derinden etkilemiş, çalışma hayatında önemli değişikliklere neden olmuştur. İşletmeler çalışma koşullarını düzenleyebilmek için temizlik, mesafe ve iş yerlerinin yeniden düzenlenmesi gibi ilave tedbirler almak zorunda kalmışlardır. Hatta pandeminin yoğun olduğu dönemlerde işletmelerin çalışmalarına ara vermeleri gerekmiştir. Ayrıca, birçok işletme uzaktan/evden çalışma ya da esnek çalışma modeline geçmiştir.

$\mathrm{Bu}$ araştırma, COVID-19 Pandemisinin insan kaynakları uygulamalarına olan etkilerinin belirlenmesi amacıyla yapılmıştır. Bu amaçla, COVID-19 Pandemisinin insan kaynakları uygulamalarından olan çalışan tedarik ve seçimi, eğitim, ücret, performans değerlendirme sistemi, kariyer gelişimi takibi ve motivasyona olan etkileri ortaya konulmaya çalışılmıştır.

Carnevale ve Hatak (2020), COVID-19 Pandemisinin, İKY için özellikle zorlu bir ortam yarattığını, İKY birimlerinin çalışanların iş çevresinde ve sosyal çevrede meydana gelen radikal değişikliklere uyum sağlamasında ve "bilinmeyen bilinmeyenlere" adapte olmalarında destek olmak zorunda kaldıklarını belirtmiştir. Örneğin, daha önce zamanlarının tamamını veya çoğunu işletmelerinin fiziksel sınırları içinde geçiren çalışanlar, artık uzaktan çalışmak zorunda kalmışlardır. Çalışanların bu yeni çalışma sistemine uyum sağlamasında İKY birimleri önemli bir rol oynamışlardır.

COVID-19 Pandemisi döneminde, işletmelerin yaklaşık üçte biri çalışanlarının bir kısmını işten çıkarmışlar ya da izne yollamışlardır. Benzer şekilde işletmelerin yaklaşık üçte biri COVID-19 krizinin uzun vadeli belirsizliğine karşı bir önlem olarak geçici işçiler çalıştırmışlardır (Campion vd., 2021). Dolayısıyla COVID-19 Pandemisi döneminde işletmelerin çalışan tedarik ve seçim politikalarında değişiklikler yapmaları gerekmiştir. Ayrıca, COVID-19 Pandemisi döneminde çalışanların salgın koşulları ve işin mevcut durumu hakkında bilgilendirme yapılmasında İKY birimleri önemli bir görev üstlenmişlerdir (Dirani vd., 2020: 383). Bu dönemde İKY'nin eğitim işlevi sayesinde çalışanların yeni çalışma koşullarına uyum sağlamalarına destek olunmuştur. COVID-19 Pandemisi döneminde bir başka önemli konu çalışan motivasyonu olmuştur. Provino’ya göre ise (2020), COVID-19 sürecinde iş gücünün büyük bir kısmı artık evde çalıştığından dolayı çalışanların sağlığı İK birimleri için yüksek bir öncelik olmalıdır. Çalışanların ofisten uzakta çalışırken olabildiğince mutlu olmaları sağlanmalıdır. Çünkü çalışan performansı çalışan mutluluğuna ve motivasyonuna bağlıdır. Eğer bu motivasyon ve mutluluk sağlanamazsa yapılan işlerin başarısı risk altına girebilir.

COVID-19 Pandemisinin yukarıda bahsedildiği gibi hem işletmeler hem de çalışanlar üzerinde önemli etkileri olmuştur. Yapılan araştırma ile bu etkiler sistematik bir 
şekilde ortaya konulmaya çalışılmıştır. Bu amaçla COVID-19 Pandemisinin İKY uygulamaları üzerinde etkili olduğuna yönelik hipotezler geliştirilmiştir. Araştırma hipotezleri paralelinde bir anket formu oluşturularak İKY sorumluları tarafından doldurulması sağlanmıştır.

Yapılan araştırma sonucunda; işletmelerin çalışan sayıları ile Pandemi sürecinde uzaktan veya esnek çalışma modeline geçmeleri arasında anlamlı ilişki olduğu; işletmelerde Pandemiden önce online iş başvurusu alınması ile Pandemi döneminde online iş başvurusu alınması arasında anlamlı ilişkinin olmadığı; işletmelerde Pandemiden önce online mülakat yapılması ile Pandemi döneminde online mülakat yapılması arasında anlamlı ilişki olduğu; işletmelerde Pandemi sürecinden önce online genel yetenek testleri yapılması ile Pandemi döneminde online genel yetenek testleri yapılması arasında anlamlı ilişki olduğu; işletmelerde Pandemiden önce online kişilik testleri yapılması ile Pandemi dönemi online kişilik testleri yapılması arasında anlamlı ilişki olduğu; Pandemi sürecinin işletmelerin İKY uygulamalarında değişiklik yapması ile eğitim uygulamaları arasında anlamlı ilişki olduğu; Pandemi sürecinin işletmelerinin İKY uygulamalarında değişiklik yapması ile ücret uygulamaları arasında anlamlı ilişki olmadığı; Pandemi döneminde çalışanların ücretlerinde değişiklik olup olmaması ile kısa çalışma ödeneğinden faydalanma arasında anlamlı ilişki olduğu; işletmelerin çalışan sayıları ile Pandemi sürecinde kısa çalışma ödeneğinden faydalanmaları arasında anlamlı ilişki olduğu; Pandemi sürecinin işletmelerin İKY uygulamalarında değişiklik yapması ile performans takip sistemleri arasında anlamlı ilişki olduğu; Pandemi sürecinin işletmelerin İKY uygulamalarında değişiklik yapması ile Pandemi sürecinde çalışanların kariyer gelişimlerinin takip edilmesi arasında anlamlı ilişki olduğu; Pandemi sürecinin işletmelerin İKY uygulamalarında değişiklik yapması ile Pandemi sürecinde çalışanların motivasyon ve memnuniyetini artırıcı faaliyetler yapılması arasında anlamlı ilişki olduğu belirlenmiştir.

Yapılan araştırma ile COVID-19 Pandemisinin İKY uygulamalarına önemli etkilerinin olduğu belirlenmiştir. Bu nedenle araştırma sonuçlarının hem işletmelere hem de literatüre önemli bir katkı sağlayacağı düşünülmektedir.

\section{Kavramsal Çerçeve}

Çin'in Hubei bölgesi başkenti olan Wuhan'da Aralık 2019'da başlayan COVID-19, önce Avrupa, Kuzey Amerika ve Asya-Pasifik ülkelerine yayılmış daha sonra tüm dünyaya yayılarak bir salgın haline dönüşmüştür (Aslan, 2020: 39). Ardından, 11 Mart 2020'de Dünya Sağlık Örgütü tarafından Pandemi olarak ilan edilmiştir (WHO, 2020). Pandemi ile beraber hayatın akışı ve ritmi tüm dünyada değişmiştir (Bozkurt, 2020: 113). COVID-19 virüsünün hızla yayılmasını kontrol etmek için dünyanın dört bir yanındaki hükümetler sınırların kapatılması, işletmelerin kapatılması (temel hizmetler hariç) dâhil olmak üzere katı kitle kontrol önlemleri almışlardır. Ayrıca, insanların yakın fiziksel temasını kısıtlayan tecrit ve sosyal mesafe kuralları koymuşlardır (Chadee vd. 2021: 1). 
Alınan önleyici tedbirler toplumun tamamını etkilemiştir. Ekonomik açıdan da Pandemiyi önleyecek tedbirlerin özellikle işgücü piyasası üzerinde kritik etkileri olmuştur. Ekonomi üzerindeki bu etki, dolaylı olarak sosyolojik ve psikolojik çıktılara da neden olmuştur (Aydın-Göktepe, 2020: 631). Hükümetler bazı endüstrilerin faaliyetlerini kısıtladığ1 ve işgörenler evlerinden çalıştığı için, pek çok sektör arzla ilgili sorunlarla karşı karşıya kalmıştır. İşletmelerin gerekli sağlık koruma önlemlerinin uygulanması, azaltılmış üretim ve talep, tedarik zinciri kesintileri dahil olmak üzere bir dizi zorlukla mücadele etmesi gerekmiştir (Kraus vd., 2020: 1068).

İnsan kaynakları yönetimi, işletmelerin hedeflerine ulaşmak için yüksek düzeyde kararlı ve nitelikli bir işgücünün etkin istihdamı ve geliştirilmesine yönelik stratejik bir yaklaşımdır (Hecklaua vd., 2016: 2). İnsan kaynakları yönetimi uygulamaları, niteliği yüksek çalışanların iş yerine kazandırılması ve bu çalışanların işletme amaçları doğrultusunda etkin bir şekilde yönlendirilmesini sağlayarak, işletmelere önemli rekabet avantajları kazandırmaktadır (Erdil vd., 2004: 102). İnsan kaynakları fonksiyonları arasında; çalışan tedarik ve seçimi, eğitim ve geliştirme, ücret yönetimi, performans değerlendirme, kariyer yönetimi, çalışan motivasyon ve memnuniyetini sağlamak sayılabilir.

COVID-19 Pandemisi ile birlikte işletmelerin İKY birimlerinin önemi artmıştır. Bunun nedeni tüm işletmelerin bu COVID-19 Pandemisinden etkilenmesi ile birlikte çalışanlar ile işletme yöneticileri arasındaki tüm koordinasyonu yürütmek durumunda kalmış olmalarıdır. Ayrıca İKY birimleri değişen iş koşullarını düzenlemek ve çalışanların bu koşullarına adapte olmasını sağlamak durumunda kalmıştır. İşletmelerin birçok mevcut uygulamayı terk edip yenilerine yöneldikleri COVID-19 Pandemisi ortamında, bu dönüşümün yansıdığı yönetim uygulamaları alanlarından biri de tüm süreçlerin koordinasyonundaki merkezi rolü nedeniyle insan kaynakları yönetimi olmuştur (İlhan, 2020: 294).

COVID-19 Pandemisi, sağlık ve güvenlik sorunlarını merkeze taşımıştır ve uluslararası işgücünün sağlık ve güvenliğini yönetmede İKY'nin rolünü ortaya koymuştur (Caligiuri vd., 2020: 700). COVID-19 Pandemisinden hemen sonra çalışanlar ve yöneticiler yaşamış oldukları belirsizlik ve virüs tehdidi nedeniyle panik ve korku hissetmişlerdir. Bu panik ve korku hissi atlatıldıktan sonra yöneticiler ve insan kaynakları yöneticileri çok kısa bir süre içinde pek çok karar vermek zorunda kalmışlardır. Bunlar arasında; kimlerin işte kalacağı ve kimlerin eve gitmesi gerektiği, çalışanların dijital alana nasıl ve nerede taşınabileceği, önceliklerin neler olduğu ve bu önceliklerin çalışanlara en iyi şekilde nasıl iletilebileceği sayılabilir (Caligiuri vd., 2020: 697).

COVID-19 Pandemisi, İKY için özellikle zorlu bir ortam yaratmıştır. Yöneticiler, çalışanların iş çevresinde ve sosyal çevrede meydana gelen radikal değişikliklere uyum sağlamasına ve bunlarla başa çıkmasına yardımcı olmak için çabalarken "bilinmeyen bilinmeyenlere" hızlı bir şekilde adapte olmak zorunda kalmışlardır. Örneğin, daha önce zamanlarının tamamını veya çoğunu işletmelerinin fiziksel sınırları içinde geçiren çalışanlar, artık uzaktan çalışma ortamlarına hızla uyum sağlamak zorunda kalmışlardır (Carnevale \& 
Hatak, 2020: 183). Bu nedenle COVID-19 Pandemisi gibi bir kriz sırasında İKY'nin rolü kritik hale gelmektedir. Kriz durumlarında İKY, çalışanların sağlık ve organizasyonel ihtiyaçlarını karşılamaya çalışır. Diğer bir İKY rolü ise, çalışanlar ve liderler arasında bir bağlantı kurmaktır. Liderlerin kriz anında çalışanları dinlemeleri ve onlara psikolojik güçlendirme desteği sağlamaları gerekir. Bu noktada İK, çalışanların işle ilgili endişelerinin dile getirilmesi ve liderlere çözümler önerilmesinde önemli bir rol oynamaktadır. Ayrıca, çalışanların güncel tutulması ve işin mevcut durumu hakkında bilgilendirme yapılmasında İKY'nin önemli bir görevi bulunmaktadır (Dirani vd., 2020: 383).

COVID-19 Pandemisi döneminde, işletmelerin yaklaşık üçte biri çalışanlarının bir kısmını işten çıkarmışlar ya da izne yollamışlardır. Ayrıca, işletmelerin neredeyse yarısı işe alımları durdurmuştur. Ancak, işletmelerin yarısı çalışan seçme ve tedarik işlemlerini belli bir düzeyde sürdürmüştür. Bununla birlikte, COVID-19 Pandemisi işletmelerin üçte birinin resmi iş tanımlarında veya işe alma stratejilerinde de değişikliklere neden olmuştur. Son olarak, işletmelerin yaklaşık üçte biri, COVID-19 krizinin uzun vadeli belirsizliğine karşı bir önlem olarak geçici işçilerden faydalanmıştır (Campion vd., 2021: 5).

İşletmeler, COVID-19 Pandemisiyle birlikte, çalışanlarını farklı bölgelerde teknik, fiziksel ve sosyo-ekonomik olarak daha önce eşi görülmemiş bir zorlukla yönetme sorunu ile karşı karşıya kalmışlardır (Carnevale \& Hatak, 2020: 183). COVID-19 Pandemisi, zaten sağlık riskinden dolayı stres altında olan birçok kişiyi evden çalışmak zorunda bırakmıştır. Bu stres faktörü ile birlikte birçok yöneticinin, bu dönemde ilk kez uzaktan çalışan ekiplere liderlik etmesi gerekmiştir (Caligiuri vd., 2020: 698). COVID-19 krizinin neden olduğu değişiklikler nedeniyle bazı çalışanların yaşadığı artan stres göz önüne alındığında, işletmelerin \%60'ında çalışan yardım programları güncellenmiş veya teşvik edilmiş ve işletmelerin \% 40' ında daha fazla ruh sağlığı ve zindelik hizmetleri sunulmuştur. Neredeyse hiçbir işletme çalışanlara yardıma verdiği önemi azaltmamıştır (Campion vd., 2021: 5).

Provino'ya göre (2020: 31), COVID-19 sürecinde iş gücünün büyük bir kısmı artık evde çalıştığından dolayı, çalışanların sağlığı İKY departmanları için yüksek bir öncelik olmalıdır. Çalışanların ofisten uzakta çalışırken olabildiğince mutlu olmaları sağlanmalıdır. Çünkü çalışan performansı çalışan mutluluğuna ve motivasyonuna bağlıdır. Eğer bu motivasyon ve mutluluk sağlanamazsa yapılan işlerin başarısı risk altına girebilir. COVID19 sürecinde, uzaktan çalışma, yalnız yaşayan ve sosyal etkileşim ihtiyacını daha çok ofiste karşılayanları olumsuz etkileyebilir. İK yöneticileri bu çalışanların motivasyon kaybını önlemek için yeni projelere veya öğrenme etkinliklerine ihtiyaç duyulabileceğini bilmelidir. İş gücünün büyük bir bölümü artık uzaktan çalışıyor olduğundan, çalışanların sağglı̆ her yerde İKY departmanları için yüksek bir öncelik olmalıdır. Her şey insanları ofisten uzakta çalışırken olabildiğince mutlu tutmakla ilgilidir (Jones, 2020: 39).

COVID-19 Pandemisi sürecinde çalışanların yaşadığı bir başka ve önemli sorun iş ve aile arasındaki çatışma potansiyelinin her zamankinden çok daha fazla olmasıdır. Özellikle uzaktan çalışmaya alışkın olmayanlar için uzaktan çalışmayı sürdürme sorunlarına ek olarak artan çocuk bakımı, aile ve arkadaşların sağlığı ve güvenliği konusundaki endişelerle de başa 
Kılıç-Kırılmaz, S. (2021), “COVID-19 Pandemisinin İnsan Kaynakları Yönetimi Üzerine Etkilerinin Belirlenmesine Yönelik Bir Araştırma”, Sosyoekonomi, 29(50), 255-276.

çıkmak gerekmektedir. Bu nedenle iş ve aile arasındaki sınırları korumak çalışanlar için her zamankinden çok daha zor bir duruma gelmiştir (Carnevale \& Hatak, 2020: 184). Dolayısıyla İKY birimlerinin olası çatışmaların çözümüne yönelik etkili stratejiler geliştirmesi gerekmektedir.

COVID-19 Pandemisinin üzerinden yaklaşık bir yıllık kısa bir süre geçmiş olmasına rağmen bu konu ile ilgili bir çok araştırma yapılmıştır. Bu çalışmalar kısaca özetlenmiştir. Kırpık (2020: 2402), yapmış olduğu çalışmada, COVID-19 Pandemisinin insan kaynakları üzerindeki etkisini, akademi, medya ve iş dünyası perspektifinden incelemiştir. İşletme yöneticilerinin geri dönüşü olmayan bir noktaya gelene kadar beklemeden, COVID-19 Pandemisi döneminde proaktif önlemler almaları ve hem kısa hem de orta vadeli stratejiler uygulamaları gerektiğini belirtmiştir. Akbaş Tuna ve Çelen (2020), işletmelerin İKY uygulamaları üzerinde COVID-19 Pandemisinin etkileri üzerinde durmuştur. İlhan (2020), COVID-19 ile mücadelede İKY uygulamalarında ihtiyaç duyulan aksiyonların belirlenmesine yönelik örgütsel müdahale yöntemi önerisi üzerinde durmuştur. Akbaş Tuna ve Türkmendağ (2020) yapmış oldukları araştırmada, COVID-19 Pandemi döneminde uzaktan çalışma uygulamaları ve çalışma motivasyonunu etkileyen faktörleri ele almışlardır. Akca ve Tepe Küçükoğlu (2020), COVID-19'un iş yaşamına etkileri ve evden çalışma üzerinde durmuşlardır. Şen ve Batı (2020), COVID-19 Pandemi krizinin yönetim ve ekonomi politikası üzerine olası etkilerini ele almışlardır. Aydın Göktepe (2020), COVID19 krizi döneminde iş sürdürülebilirliğine yönelik yönetim uygulamalarını incelemiştir. Sayan (2020), COVID-19 Pandemisi sürecinde öğretim elemanlarının uzaktan eğitime ilişkin görüşlerini değerlendirilmiştir. Demir vd. (2020), COVID-19 Pandemisinin Türkiye'de turizm üzerindeki öncülleri, etkileri ve sonuçlarını incelemişlerdir. Serinikli (2021), COVID-19 Pandemisi sürecinde örgütsel değişimi uzaktan/evden çalışma modeli ile değerlendirmiştir. Acar (2020), COVID-19 Pandemisi ve turizm faaliyetlerine etkisini araştırmıştır. Ateş (2020), COVID-19'un işverenin iş sağlığ 1 ve güvenliği konusunda alması gereken önlemlere etkisini değerlendirmiştir. Bozkurt (2020), COVID-19 pandemi süreci ve pandemi sonrası dünyada eğitime yönelik değerlendirmeler ile yeni normal ve yeni eğitim paradigması üzerinde durmuştur. Dönmez ve Gürbüz (2020), üniversite öğrencilerinin COVID-19 virüsü hakkında bilişsel yapılarının belirlenmesini incelemişlerdir. Yılmaz (2020), COVID-19 Pandemi sürecinin kamu çalışanları üzerine etkisini araştırmıştır. Akıncı (2020), COVID-19 Pandemisi kapsamında şirket yöneticilerinin almaları gereken önlemleri değerlendirmiştir. Yakut vd. (2020), sağlık personelinin COVID-19 korkusu ile tükenmişliği arasındaki ilişkide aşırı iş yükü ve algılanan sosyal desteğin etkisinin yapısal eşitlik modeliyle belirlenmesi üzerinde durmuşlardır. Şener ve Abunasser (2020), bireysel öncüllerinin iş-aile çatışmasına etkisinde, COVID-19 pandemisi nedeniyle evden çalışanlar üzerindeki etkisini araştırmışlardır. Lloyd-Jones (2021), insan ilişkileri/insan kaynakları geliştirme yaklaşımı ile COVID-19 Pandemisi sırasında duygusal, araçsal ve bilgilendirici öğrenci desteği için yetkinliklerin geliştirilmesi üzerinde durmuştur.

Yapılan araştırmalar dikkate alındığında COVID-19 Pandemisinin bir çok alana olduğu gibi insan Kaynakları üzerinde de önemli etkileri olmuştur. COVID-19 Pandemisi ile birlikte işletmelerde iş yapma biçimleri değişmiştir. Bunlardan en önemlisi uzaktan 
çalışma sistemine geçilmiş olmasıdır. Aynı şekilde İK tedarik ve seçimi, eğitim, ücret politikaları, performans yönetimi, kariyer yönetimi ve motivasyon gibi bir çok insan kaynakları uygulamaları üzerinde COVID-19 Pandemisinin etkileri olmuştur.

\section{Araştırmanın Yöntemi}

COVID-19 Pandemisinin İKY'ye etkilerinin belirlenmesi amacıyla yapılan bu araştırmada, nicel araştırma yönteminden faydalanılmıştır. Araştırma için 23 maddeden oluşan bir soru formu oluşturulmuştur. Soru formunun oluşturulmasında geniş bir literatür taraması yapılmıştır. COVID-19 Pandemisinin insan kaynaklarına etkileri hakkında literatürde tartışılan en önemli konular soru formuna eklenmiştir. Soru formunun oluşturulmasında Mercer (2020), “COVID-19 Salgınının Türkiye’de Çalışma Hayatı Üzerine Etkileri Anketi”, Deloitte (2020), "COVID-19 Workforce Strategies for PostCOVID- Recovery, Ahrendt vd. (2020), "Living, Working and COVID-19" ve ILO (2020), "Teleworking During the COVID-19 Pandemic and Beyond: A Practical Guide" raporlarından faydalanılmıştır.

Araştırma için Sakarya Uygulamalı Bilimler Üniversitesi Etik Kurulundan 19.02.2021 tarih ve E-26428519-044-4880 sayı ile etik kurul izni alınmıştır. Araştırmada kolayda örnekleme yöntemi kullanılmış olup, oluşturulan soru formu katılımcılara LinkedIn sosyal ağı üzerinden online olarak gönderilmiş ve doldurmaları istenmiştir. Bu yolla analiz edilebilir 240 adet anket toplanmış ve analizler bu anketler üzerinden gerçekleştirilmiştir. Elde edilen verilerin analizinde SPSS paket programı kullanılmıştır. Araştırma hipotezlerini test etmek için Ki-Kare analizinden yararlanılmıştır. Araştırma için geliştirilen hipotezler aşağıdaki gibidir:

$H_{1:}$ Işsletmelerin çalışan sayıları ile Pandemi sürecinde uzaktan veya esnek çalışma modeline geçmeleri arasında anlamlı ilişki vardır.

$\mathrm{H}_{2 a}$ : Işletmelerde Pandemiden önce online iş başvurusu alınması ile Pandemi döneminde online iş başvurusu alınması arasında anlamlı ilişki vardır.

$H_{2 b:}$ Işletmelerde Pandemiden önce online mülakat yapılması ile Pandemi döneminde online mülakat yapılması arasında anlamlı ilişki vardır.

$H_{2 c:}$ Işletmelerde Pandemi sürecinden önce online genel yetenek testleri yapılması ile Pandemi döneminde online genel yetenek testleri yapılması arasında anlamlı ilişki vardır.

$H_{2 d:}$ Işsletmelerde Pandemiden önce online kişilik testleri yapılması ile Pandemi döneminde online kişilik testleri yapılması arasında anlamlı ilişki vardır.

$H_{3:}$ Pandemi sürecinin işletmelerin IKY uygulamalarında değişiklik yapması ile ĕgitim uygulamaları arasında anlamlı ilişki vardır.

$H_{4:}$ Pandemi sürecinin işletmelerinin IKY uygulamalarında değişiklik yapması ile ücret uygulamaları arasında anlamlı ilişki vardır.

$H_{5:}$ Pandemi döneminde çalışanların ücretlerinde değişiklik olup olmaması ile klsa çalışma ödeneğinden faydalanma arasında anlamlı ilişki vardır. 
H.: Işsletmelerin çalışan sayıları ile Pandemi sürecinde kısa çalışma ödeneğinden faydalanmaları arasında anlamlı ilişki vardır.

$H_{7:}$ Pandemi sürecinin işletmelerin IKY uygulamalarında değişiklik yapması ile performans takip sistemleri arasında anlamlı ilişki vardır.

$H_{8}$ : Pandemi sürecinin işletmelerin IKY uygulamalarında değişiklik yapması ile Pandemi sürecinde çalışanların kariyer gelişimlerinin takip edilmesi arasında anlamlı ilişki vardır.

H9: Pandemi sürecinin işletmelerin IKY uygulamalarında değişiklik yapması ile Pandemi sürecinde çalışanların motivasyon ve memnuniyetini artırıcı faaliyetler yapılması arasında anlamlı ilişki vardır.

\section{Bulgular}

Sektöre göre çalışan sayıları incelenerek sonuçlar Tablo 1'de gösterilmiştir. Sektöre göre çalışan sayılarına bakıldığında; Bilişim 7, Diğer 23, Eğitim 13, Elektronik 11, Enerji 8, Gıda 32, İmalat 20, İnşaat 6, Lojistik 19, İletişim 5, Metal 18, Otomotiv 32, Sağlık 13, Tekstil 22 ve Turizm 11 şeklinde bir dağılım olduğu görülmektedir.

Tablo: 1

Sektöre Göre Çalışan Sayısı

\begin{tabular}{|c|c|c|c|c|c|}
\hline \multirow{2}{*}{ Sektör } & \multicolumn{4}{|c|}{ Çalışan Sayısı } & \multirow[b]{2}{*}{ Toplam } \\
\hline & & $1-49$ & $50-249$ & $250+$ & \\
\hline \multirow{2}{*}{ Bilişim } & f & 4 & 1 & 2 & 7 \\
\hline & $\%$ & 57,1 & 14,3 & 28,6 & 100,0 \\
\hline \multirow{2}{*}{ Diğer } & $\mathrm{f}$ & 3 & 9 & 11 & 23 \\
\hline & $\%$ & 13,0 & 39,1 & 47,8 & 100,0 \\
\hline \multirow{2}{*}{ Eğitim } & $f$ & 7 & 1 & 5 & 13 \\
\hline & $\%$ & 53,8 & 7,7 & 38,5 & 100,0 \\
\hline \multirow{2}{*}{ Elektronik } & f & 1 & 5 & 5 & 11 \\
\hline & $\%$ & 9,1 & 45,5 & 45,5 & 100,0 \\
\hline \multirow{2}{*}{ Enerji } & f & 0 & 2 & 6 & 8 \\
\hline & $\%$ &, 0 & 25,0 & 75,0 & 100,0 \\
\hline \multirow{2}{*}{ Gida } & f & 3 & 5 & 24 & 32 \\
\hline & $\%$ & 9,4 & 15,6 & 75,0 & 100,0 \\
\hline \multirow[b]{2}{*}{ İmalat } & $\mathrm{f}$ & 1 & 6 & 13 & 20 \\
\hline & $\%$ & 5,0 & 30,0 & 65,0 & 100,0 \\
\hline \multirow{2}{*}{ İnşaat } & $\mathrm{f}$ & 2 & 1 & 3 & 6 \\
\hline & $\%$ & 33,3 & 16,7 & 50,0 & 100,0 \\
\hline \multirow{2}{*}{ Lojistik } & f & 1 & 7 & 11 & 19 \\
\hline & $\%$ & 5,3 & 36,8 & 57,9 & 100,0 \\
\hline \multirow{2}{*}{ İletişim } & f & 1 & 1 & 3 & 5 \\
\hline & $\%$ & 20,0 & 20,0 & 60,0 & 100,0 \\
\hline \multirow{2}{*}{ Metal } & $\mathrm{f}$ & 2 & 6 & 10 & 18 \\
\hline & $\%$ & 11,1 & 33,3 & 55,6 & 100,0 \\
\hline \multirow{2}{*}{ Otomotiv } & $\mathrm{f}$ & 3 & 12 & 17 & 32 \\
\hline & $\%$ & 9,4 & 37,5 & 53,1 & 100,0 \\
\hline \multirow{2}{*}{ Sağlık } & f & 0 & 5 & 8 & 13 \\
\hline & $\%$ & 0 & 38,5 & 61,5 & 100,0 \\
\hline \multirow{2}{*}{ Tekstil } & f & 1 & 9 & 12 & 22 \\
\hline & $\%$ & 4,5 & 40,9 & 54,5 & 100,0 \\
\hline \multirow{2}{*}{ Turizm } & f & 2 & 3 & 6 & 11 \\
\hline & $\%$ & 18,2 & 27,3 & 54,5 & 100,0 \\
\hline \multirow{2}{*}{ Toplam } & f & 31 & 73 & 136 & 240 \\
\hline & $\%$ & 12,9 & 30,4 & 56,7 & 100,0 \\
\hline
\end{tabular}

Çalışan sayısına göre işletmelerin Pandemi döneminde çalışan sayılarındaki değişim Tablo 2'de görülmektedir. Tablo 2'ye göre; 1-49 sayıda çalışanı olan işletmelerin 
\%25,8'inin çalışan sayısı artmış \%22, 6'sının çalışan sayısı azalmışken yarıdan fazlasının $(\% 51,6)$ çalışan sayısının değişmediği görülmektedir. 50-249 sayıda çalışanı olan işletmelerin \%30,1'nin çalışan sayısı artmışken \%20,5'nin çalışan sayısı azalmıştır. Bununla birlikte bu gruptaki işletmelerin yarıya yakınının $(\% 49,3)$ çalışan sayısında değişiklik olmadığ1 görülmektedir. 250 ve üzeri çalışan sayısı olan işletmelerin \%34,6'nın çalışan sayısı artmışken \% 18,4'nün çalışan sayısının azaldığı, yine yarıya yakınının $(\% 47,1)$ çalışan sayısının değişmediği görülmektedir.

Tablo: 2

Mevcut Çalışan Sayısına Göre Pandemi Dönemi Çalışan Sayısı Değişimi

\begin{tabular}{|c|c|c|c|c|c|c|}
\hline & & & \multicolumn{3}{|c|}{ Çalıșan Sayısındaki Değişim } & \multirow{2}{*}{ Toplam } \\
\hline & & & Artt1 & Azaldi & Değişmedi & \\
\hline \multirow{6}{*}{ Mevcut Çalışan Sayısı } & \multirow{2}{*}{$1-49$} & $\mathrm{f}$ & 8 & 7 & 16 & 31 \\
\hline & & $\%$ & 25,8 & 22,6 & 51,6 & 100,0 \\
\hline & \multirow{2}{*}{$50-249$} & $\mathrm{f}$ & 22 & 15 & 36 & 73 \\
\hline & & $\%$ & 30,1 & 20,5 & 49,3 & 100,0 \\
\hline & \multirow{2}{*}{$250+$} & $\mathrm{f}$ & 47 & 25 & 64 & 136 \\
\hline & & $\%$ & 34,6 & 18,4 & 47,1 & 100,0 \\
\hline & \multirow{2}{*}{ Toplam } & $\mathrm{f}$ & 77 & 47 & 116 & 240 \\
\hline & & $\%$ & 32,1 & 19,6 & 48,3 & 100,0 \\
\hline
\end{tabular}

İşletmelerin çalışan sayıları ile Pandemi sürecinde uzaktan veya esnek çalışma modeline geçip geçmedikleri arasındaki ilişkiyi incelemek amacıyla Ki-Kare (Chi-Square ұ) analizi yapılmıştır. Elde edilen bulgular Tablo 3 'te sunulmuştur.

İşletmelerin çalışan sayıları ile Pandemi sürecinde uzaktan veya esnek çalışma modeline geçip geçmemeleri arasındaki ilişkiyi belirlemek amacıyla yapılan Chi-square $\left(\chi^{2}\right)$ testi bulguları iki değișken arasında istatistiksel olarak anlamlı ilişki olduğunu göstermiştir $\left(\chi^{2}=18,858 ; \mathrm{p}=0,004\right)$. Elde edilen bulgular neticesinde araştırmada ileri sürülen " $\mathrm{H}_{1}$ : İşletmelerin çalışan sayllarl ile Pandemi sürecinde uzaktan veya esnek çalışma modeline geçmeleri arasında anlamlı ilişki vardır. " hipotezi kabul edilmiştir.

Tablo: 3

Çalışan Sayısına Göre Uzaktan veya Esnek Çalışma Modeline Geçilmesi

\begin{tabular}{|c|c|c|c|c|c|c|c|c|c|c|}
\hline & \multicolumn{4}{|c|}{ Uzaktan veya Esnek Çalışma Modeline Geçilmesi } & \multirow[b]{2}{*}{ Toplam } & \multirow[b]{2}{*}{$\chi^{2}$} & \multirow[b]{2}{*}{ df } & \multirow[b]{2}{*}{$\mathrm{p}$} \\
\hline & & & $\begin{array}{c}\text { Tamamen uzaktan } \\
\text { çalışma modeli uygulandı }\end{array}$ & $\begin{array}{c}\text { Dönüşümlü esnek } \\
\text { çalşsma modeli } \\
\text { uygulandı }\end{array}$ & $\begin{array}{c}\text { Bazen uzaktan } \\
\text { bazen de esnek } \\
\text { çalışma modeli uygulandı }\end{array}$ & Hayır & & & & \\
\hline \multirow{6}{*}{$\begin{array}{c}\text { Çalışan } \\
\text { Sayıs1 }\end{array}$} & \multirow{2}{*}{$1-49$} & $\mathrm{f}$ & 5 & 4 & 16 & 6 & 31 & \multirow{8}{*}{18,858} & \multirow{8}{*}{6} & \multirow{8}{*}{,004 } \\
\hline & & $\%$ & 16,1 & 12,9 & 51,6 & 19,4 & 100,0 & & & \\
\hline & \multirow{2}{*}{$50-249$} & $\mathrm{f}$ & 1 & 12 & 33 & 27 & 73 & & & \\
\hline & & $\%$ & 1,4 & 16,4 & 45,2 & 37,0 & 100,0 & & & \\
\hline & \multirow{2}{*}{$250+$} & $\mathrm{f}$ & 7 & 29 & 76 & 24 & 136 & & & \\
\hline & & $\%$ & 5,1 & 21,3 & 55,9 & 17,6 & 100,0 & & & \\
\hline \multirow{2}{*}{\multicolumn{2}{|c|}{ Toplam }} & $\mathrm{f}$ & 13 & 45 & 125 & 57 & 240 & & & \\
\hline & & $\%$ & 5,4 & 18,8 & 52,1 & 23,8 & 100,0 & & & \\
\hline
\end{tabular}

İşletmelerde Pandemiden önce online iş başvurusu alınması ile Pandemi sorası online iş başvurusu alınması arasındaki ilişkiyi incelemek amacıyla Ki-Kare (Chi-Square - $\chi 2$ ) analizi gerçekleştirilmiştir. Elde edilen bulgular Tablo 4'te yer almaktadır. 
Pandemiden önce katılımcıların işletmelerinde online iş başvurusu alınması ile Pandemi dönemi online iş başvurusu alınması arasındaki ilişkiyi belirlemek amacıyla yapılan Chi-square $\left(\chi^{2}\right)$ testi bulguları iki değişken arasında istatistiksel olarak anlamlı bir ilişki olmadığını göstermiştir $\left(\chi^{2}=3,289 ; \mathrm{p}=0,193\right)$. Elde edilen bulgular neticesinde araştırmada ileri sürülen " $\mathrm{H}_{2 \mathrm{a}}$ I Işletmelerde Pandemiden önce online iş başvurusu alınması ile Pandemi döneminde online iş başvurusu alınması arasında anlamlı ilişki vardır." hipotezi kabul edilmemiştir.

\section{Tablo: 4}

\section{Pandemi Öncesi ve Pandemi Dönemi Online İş Başvurusu Alma}

\begin{tabular}{|c|c|c|c|c|c|c|c|c|c|}
\hline & & & Pan & önemi Onlin & urusu & & & & \\
\hline & & & Artt1 & Değişmedi & Azald1 & Toplam & $\chi^{-}$ & df & $\mathrm{p}$ \\
\hline \multirow{6}{*}{ Pandemi Öncesi Online İş Başvurusu } & \multirow{2}{*}{ Evet } & $f$ & 112 & 74 & 5 & 191 & \multirow{6}{*}{3,289} & \multirow{6}{*}{2} & \multirow{6}{*}{, 193 } \\
\hline & & $\%$ & 58,6 & 38,7 & 2,6 & 100,0 & & & \\
\hline & \multirow{2}{*}{ Hayır } & $\mathrm{f}$ & 22 & 26 & 1 & 49 & & & \\
\hline & & $\%$ & 44,9 & 53,1 & 2,0 & 100,0 & & & \\
\hline & \multirow{2}{*}{ Toplam } & $\mathrm{f}$ & 134 & 100 & 6 & 240 & & & \\
\hline & & $\%$ & 55,8 & 41,7 & 2,5 & 100,0 & & & \\
\hline
\end{tabular}

İşletmelerde Pandemiden önce online mülakat yapılması ile Pandemiden döneminde online mülakat yapılması arasındaki ilişkiyi incelemek amacıyla Ki-Kare (Chi-Square - $\chi 2$ ) analizi gerçekleştirilmiştir. Elde edilen bulgular Tablo 5 'te sunulmuştur.

İşletmelerde Pandemiden önce online mülakat yapılması ile Pandemi dönemi online mülakat yapılması arasındaki ilişkiyi incelemek amacıyla Chi-square $\left(\chi^{2}\right)$ testi bulguları iki değişken arasında istatistiksel olarak anlamlı bir ilişki olduğunu göstermiştir $\left(\chi^{2}=19,351\right.$; $\mathrm{p}=0,000)$. Elde edilen bulgular neticesinde araştırmada ileri sürülen " $\mathrm{H}_{2 \mathrm{~b}}$ : Işsletmelerde Pandemiden önce online mülakat yapılması ile Pandemi döneminde online mülakat yapılması arasında anlamlı ilişki vardır. ” hipotezi kabul edilmiştir.

\section{Tablo: 5}

\section{Pandemi Öncesi ve Pandemi Dönemi Online Mülakat}

\begin{tabular}{|c|c|c|c|c|c|c|c|c|c|}
\hline & & & & Dönemi On & akat & & & & \\
\hline & & & Artt1 & Değişmedi & Azaldı & Toplam & $\chi^{2}$ & $\mathrm{df}$ & $\mathrm{p}$ \\
\hline \multirow{4}{*}{ Pandemi Öncesi Online Mülakat } & \multirow{2}{*}{ Evet } & $\mathrm{f}$ & 79 & 16 & 2 & 97 & \multirow{6}{*}{19,351} & \multirow{6}{*}{2} & \multirow{6}{*}{, 000} \\
\hline & & $\%$ & 81,4 & 16,5 & 2,1 & 100,0 & & & \\
\hline & \multirow{2}{*}{ Hayır } & $\mathrm{f}$ & 77 & 59 & 7 & 143 & & & \\
\hline & & $\%$ & 53,8 & 41,3 & 4,9 & 100,0 & & & \\
\hline & \multirow{2}{*}{ Toplam } & $\mathrm{f}$ & 156 & 75 & 9 & 240 & & & \\
\hline & & $\%$ & 65,0 & 31,3 & 3,8 & 100,0 & & & \\
\hline
\end{tabular}

İşletmelerde Pandemiden önce online genel yetenek testleri yapılması ile Pandemi döneminde online genel yetenek testleri yapılması arasındaki ilişkiyi incelemek amacıyla

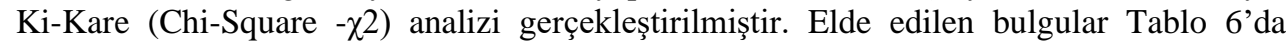
sunulmuştur.

İşletmelerde Pandemiden önce online genel yetenek testleri yapılması ile Pandemi dönemi online genel yetenek testleri yapılması arasındaki ilişkiyi belirlemek amacıyla yapılan Chi-square $\left(\chi^{2}\right)$ testi bulguları iki değişken arasında istatistiksel olarak anlamlı bir 
ilişki olduğunu göstermiştir $\left(\chi^{2}=12,756 ; \mathrm{p}=0,002\right)$. Elde edilen bulgular neticesinde

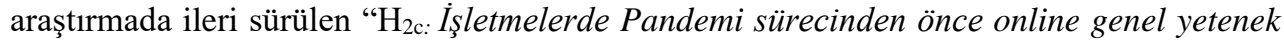
testleri yapılması ile Pandemi dönemi online genel yetenek testleri yapılması arasında anlamlı ilişki vardır." hipotezi kabul edilmiştir.

Tablo: 6

Pandemi Öncesi ve Pandemi Dönemi Online Genel Yetenek Testleri

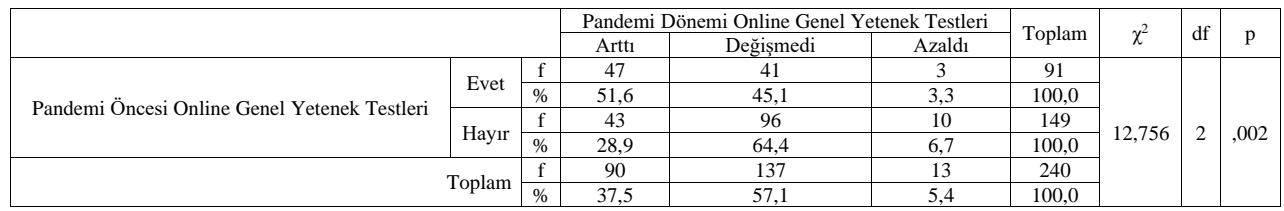

İşletmelerde Pandemiden önce online kişilik testleri yapılması ile Pandemi döneminde online kişilik testleri yapılması arasındaki ilişkiyi incelemek amacıyla Ki-Kare

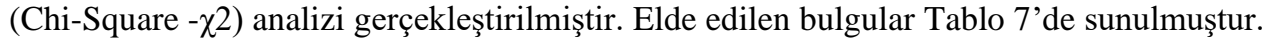

İşletmelerde Pandemiden önce online kişilik testleri yapılması ile Pandemi dönemi online kişilik testleri yapılması arasındaki ilişkiyi belirlemek amacıyla yapılan Chi-square $\left(\chi^{2}\right)$ testi bulguları iki değişken arasında istatistiksel olarak anlamlı bir ilişki olduğunu göstermiştir $\left(\chi^{2}=6,714 ; \mathrm{p}=0,035\right)$. Elde edilen bulgular neticesinde araştırmada ileri sürülen " $\mathrm{H}_{2 \mathrm{~d}}$ : Işsletmelerde Pandemiden önce online kişilik testleri yapılması ile Pandemi dönemi online kişilik testleri yapılması arasında anlamlı ilişki vardır. ” hipotezi kabul edilmiştir.

Tablo: 7

Pandemi Öncesi ve Pandemi Dönemi Online Kişilik Testleri

\begin{tabular}{|c|c|c|c|c|c|c|c|c|c|}
\hline & & & \multicolumn{3}{|c|}{ Pandemi Dönemi Online Kișilik Testleri } & \multirow{2}{*}{ Toplam } & \multirow{2}{*}{$\chi^{2}$} & \multirow{2}{*}{ df } & \multirow[b]{2}{*}{$\mathrm{p}$} \\
\hline & & & Artt1 & Değişmedi & Azaldı & & & & \\
\hline \multirow{6}{*}{ Pandemi Öncesi Online Kişilik Testleri } & \multirow{2}{*}{ Evet } & $\mathrm{f}$ & 41 & 46 & 3 & 90 & \multirow{6}{*}{6,714} & \multirow{6}{*}{2} & \multirow{6}{*}{,035 } \\
\hline & & $\%$ & 45,6 & 51,1 & 3,3 & 100,0 & & & \\
\hline & \multirow{2}{*}{ Hayır } & $\mathrm{f}$ & 44 & 97 & 9 & 150 & & & \\
\hline & & $\%$ & 29,3 & 64,7 & 6,0 & 100,0 & & & \\
\hline & \multirow{2}{*}{ Toplam } & $\mathrm{f}$ & 85 & 143 & 12 & 240 & & & \\
\hline & & $\%$ & 35,4 & 59,6 & 5,0 & 100,0 & & & \\
\hline
\end{tabular}

Pandemi sürecinin işletmelerin İKY uygulamalarında değişiklik yapması ile eğitim

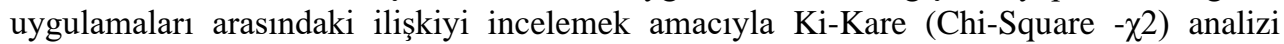
gerçekleştirilmiştir. Elde edilen bulgular Tablo 8'de sunulmuştur.

Pandemi sürecinin işletmelerin İKY uygulamalarında değişiklik yapması ile eğitim uygulamaları arasındaki ilişkiyi belirlemek amacıyla yapılan Chi-square $\left(\chi^{2}\right)$ testi bulguları iki değişken arasında istatistiksel olarak anlamlı bir ilişki olduğunu göstermiştir $\left(\chi^{2}=24,201\right.$; $\mathrm{p}=0,000$ ). Elde edilen bulgular neticesinde araştırmada ileri sürülen " $\mathrm{H}_{3}$ : Pandemi sürecinin işletmelerin IKY uygulamalarında değişiklik yapması ile ĕgitim uygulamaları arasında anlamlı ilişki vardır. ” hipotezi kabul edilmiştir. 
Tablo: 8

Pandemi Dönemi İKY ile Eğitimde Yaşanan Değişiklikler

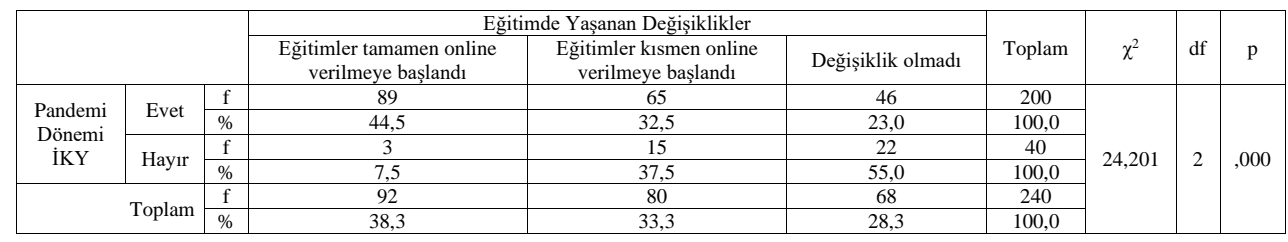

Pandemi sürecinin işletmelerin İKY uygulamalarında değişiklik yapması ile ücret uygulamaları arasındaki ilişkiyi incelemek amacıyla Ki-Kare (Chi-Square - $\chi 2$ ) analizi gerçekleştirilmiştir. Elde edilen bulgular Tablo 9'da sunulmuştur.

Pandemi sürecinin işletmelerin İKY uygulamalarında değişiklik yapması ile ücret uygulamaları arasındaki ilişkiyi belirlemek amacıyla yapılan Chi-square $\left(\chi^{2}\right)$ testi bulguları iki değişken arasında istatistiksel olarak anlamlı bir ilişki olmadığını göstermiştir $\left(\chi^{2}=2,648\right.$; $\mathrm{p}=, 266$ ). Elde edilen bulgular neticesinde araştırmada ileri sürülen " $\mathrm{H}_{4:}$ Pandemi sürecinin işletmelerinin IKY uygulamalarında değişiklik yapması ile ücret uygulamaları arasında anlamlı ilişki vardır." hipotezi kabul edilmemiştir.

Tablo: 9

Pandemi Dönemi İKY ile Ücret Değișikliği

\begin{tabular}{|c|c|c|c|c|c|c|c|c|c|}
\hline & & & & Ücret D & & & & & \\
\hline & & & Artt1 & Azald1 & Değişmedi & Ioplam & $x^{-}$ & dI & $\mathrm{p}$ \\
\hline \multirow{4}{*}{ Pandemi Dönemi İKY } & \multirow{2}{*}{ Evet } & $\mathrm{f}$ & 42 & 10 & 148 & 200 & \multirow{6}{*}{2,648} & \multirow{6}{*}{2} & \multirow{6}{*}{,266 } \\
\hline & & $\%$ & 21,0 & 5,0 & 74,0 & 100,0 & & & \\
\hline & \multirow{2}{*}{ Hayır } & $\mathrm{f}$ & 11 & 0 & 29 & 40 & & & \\
\hline & & $\%$ & 27,5 &, 0 & 72,5 & 100,0 & & & \\
\hline & \multirow{2}{*}{ Toplam } & $\mathrm{f}$ & 53 & 10 & 177 & 240 & & & \\
\hline & & $\%$ & 22,1 & 4,2 & 73,8 & 100,0 & & & \\
\hline
\end{tabular}

Pandemi döneminde çalışanların ücretlerinde değişiklik olup olmaması ile kısa çalışma ödeneğinden faydalanma arasındaki ilişkiyi incelemek amacıyla Ki-Kare (ChiSquare - $\chi 2$ ) analizi gerçekleştirilmiştir. Elde edilen bulgular Tablo 10'da sunulmuştur.

Tablo: 10

Ücret ve Kısa Çalışma Ödeneğinden Faydalanma

\begin{tabular}{|c|c|c|c|c|c|c|c|c|}
\hline & & & \multicolumn{2}{|c|}{ Kısa Calıșma Ödeneğinden Faydalanma } & \multirow{2}{*}{ Toplam } & \multirow{2}{*}{$\chi^{2}$} & \multirow{2}{*}{ df } & \multirow[b]{2}{*}{$\mathrm{p}$} \\
\hline & & & Evet & Hayır & & & & \\
\hline \multirow{6}{*}{ Ücret } & & $\mathrm{f}$ & 28 & 25 & 53 & \multirow{8}{*}{8,395} & \multirow{8}{*}{2} & \multirow{8}{*}{,015 } \\
\hline & Artt1 & $\%$ & 52,8 & 47,2 & 100,0 & & & \\
\hline & \multirow{2}{*}{ Azald 1} & $\mathrm{f}$ & 10 & 0 & 10 & & & \\
\hline & & $\%$ & 100,0 & , 0 & 100,0 & & & \\
\hline & \multirow{2}{*}{ Değişmedi } & $\mathrm{f}$ & 114 & 63 & 177 & & & \\
\hline & & $\%$ & 64,4 & 35,6 & 100,0 & & & \\
\hline \multirow{2}{*}{\multicolumn{2}{|c|}{ Toplam }} & $\mathrm{f}$ & 152 & 88 & 240 & & & \\
\hline & & $\%$ & 63,3 & 36,7 & 100,0 & & & \\
\hline
\end{tabular}

Pandemi döneminde çalışanların ücretlerinde değişiklik olup olmaması ile kısa çalışma ödeneğinden faydalanma arasındaki ilişkiyi belirlemek amacıyla yapılan Chi-square 
$\left(\chi^{2}\right)$ testi bulguları iki değişken arasında istatistiksel olarak anlamlı bir ilişki olduğunu göstermiştir $\left(\chi^{2}=8,395 ; \mathrm{p}=0,015\right)$. Elde edilen bulgular neticesinde araştırmada ileri sürülen " $\mathrm{H}_{5:}$ Pandemi döneminde çalışanların ücretlerinde değişiklik olup olmaması ile kısa çalışma ödeneğinden faydalanma arasında anlamlı ilişki vardır.” hipotezi kabul edilmiştir.

İşletmelerin çalışan sayıları ile Pandemi sürecinde kısa çalışma ödeneğinden faydalanmaları arasındaki ilişkiyi incelemek amacıyla Ki-Kare (Chi-Square - 2 ) analizi gerçekleştirilmiştir. Elde edilen bulgular Tablo 11'de sunulmuştur.

İşletmelerin çalışan sayıları ile Pandemi sürecinde kısa çalışma ödeneğinden faydalanmaları arasındaki ilişkiyi belirlemek amacıyla yapılan Chi-square $\left(\boldsymbol{\chi}^{\mathbf{2}}\right)$ testi bulguları iki değişken arasında istatistiksel olarak anlamlı bir ilişki olduğunu göstermiştir $\left(\chi^{2}=9,404\right.$; $\mathrm{p}=0,009)$. Elde edilen bulgular neticesinde araştırmada ileri sürülen " $\mathrm{H}_{6:}$ İşletmelerin çalışan sayıları ile Pandemi sürecinde kısa çalışma ödeneğinden faydalanmaları arasında anlamlı ilişki vardır." hipotezi kabul edilmiştir.

Tablo: 11

Çalışan Sayısına Göre Kısa Çalışma Ödeneğinden Faydalanma

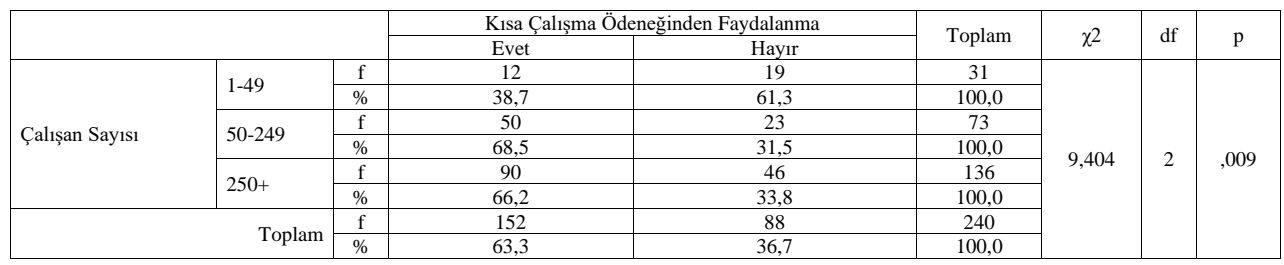

Pandemi sürecinin işletmelerin İKY uygulamalarında değişiklik yapması ile performans takip sistemleri arasındaki ilişkiyi incelemek amacıyla Ki-Kare (Chi-Square ұ2) analizi gerçekleştirilmiştir. Elde edilen bulgular Tablo 12'de sunulmuştur.

Tablo: 12

\section{Pandemi Dönemi İKY ile Performans Takip Sistemi}

\begin{tabular}{|c|c|c|c|c|c|c|c|c|c|}
\hline & \multicolumn{3}{|c|}{ Performans Takip Sistemi } & \multirow[b]{2}{*}{ Toplam } & \multirow[b]{2}{*}{$\chi^{2}$} & \multirow[b]{2}{*}{ df } & \multirow[b]{2}{*}{$\mathrm{p}$} \\
\hline & & & Değişiklik olmadı & Kısmen online hale getirildi & Tamamen online hale getirildi & & & & \\
\hline \multirow{4}{*}{ Pandemi Dönemi İKY } & Fyet & $\mathrm{f}$ & 140 & 41 & 19 & 200 & \multirow{6}{*}{10,940} & \multirow{6}{*}{2} & \multirow{6}{*}{,004 } \\
\hline & Evet & $\%$ & 70,0 & 20,5 & 9,5 & 100,0 & & & \\
\hline & \multirow{2}{*}{ Hayır } & $\mathrm{f}$ & 38 & 1 & 1 & 40 & & & \\
\hline & & $\%$ & 95,0 & 2,5 & 2,5 & 100,0 & & & \\
\hline \multirow{2}{*}{\multicolumn{2}{|c|}{ Toplam }} & $\mathrm{f}$ & 178 & 42 & 20 & 240 & & & \\
\hline & & $\%$ & 74,2 & 17,5 & 8,3 & 100,0 & & & \\
\hline
\end{tabular}

Pandemi sürecinin işletmelerin İKY uygulamalarında değişiklik yapması ile performans takip sistemleri arasındaki ilişkiyi belirlemek amacıyla yapılan Chi-square $\left(\chi^{\mathbf{2}}\right)$ testi bulguları iki değişken arasında istatistiksel olarak anlamlı bir ilişki olduğunu göstermiştir $\left(\chi^{2}=10,940 ; \mathrm{p}=0,004\right)$. Elde edilen bulgular neticesinde araştırmada ileri sürülen "H7: Pandemi sürecinin işletmelerin IKY uygulamalarında değişiklik yapması ile performans takip sistemleri arasında anlaml ilişki vardır. ” hipotezi kabul edilmiştir. 
Pandemi sürecinin işletmelerin İKY uygulamalarında değişiklik yapması ile Pandemi sürecinde çalışanların kariyer gelişimlerinin takip edilmesi arasındaki ilişkiyi incelemek amacıyla Ki-Kare (Chi-Square - $\chi 2$ ) analizi gerçekleştirilmiştir. Elde edilen bulgular Tablo 13 'te sunulmuştur.

Tablo: 13

Pandemi Dönemi İKY ile Kariyer Takibi

\begin{tabular}{|c|c|c|c|c|c|c|c|c|}
\hline & & & & kibi & & & & \\
\hline & & & Evet & Hayır & Toplam & $\chi^{2}$ & dt & $\mathrm{p}$ \\
\hline \multirow{4}{*}{ Pandemi Dönemi İKY } & \multirow{2}{*}{ Evet } & $\mathrm{f}$ & 150 & 50 & 200 & \multirow{6}{*}{6,566} & \multirow{6}{*}{1} & \multirow{6}{*}{,010 } \\
\hline & & $\%$ & 75,0 & 25,0 & 100,0 & & & \\
\hline & \multirow{2}{*}{ Hayır } & $\mathrm{f}$ & 22 & 18 & 40 & & & \\
\hline & & $\%$ & 55,0 & 45,0 & 100,0 & & & \\
\hline & \multirow{2}{*}{ Toplam } & $\mathrm{f}$ & 172 & 68 & 240 & & & \\
\hline & & $\%$ & 71,7 & 28,3 & 100,0 & & & \\
\hline
\end{tabular}

Pandemi sürecinin işletmelerin İKY uygulamalarında değişiklik yapması ile Pandemi sürecinde çalışanların kariyer gelişimlerinin takip edilmesi arasındaki ilişkiyi belirlemek amacıyla yapılan Chi-square $\left(\boldsymbol{\chi}^{2}\right)$ testi bulguları iki değişken arasında istatistiksel olarak anlamlı bir ilişki olduğunu göstermiştir $\left(\chi^{2}=6,566 ; \mathrm{p}=0,010\right)$. Elde edilen bulgular neticesinde araştırmada ileri sürülen " $H_{8}$ : Pandemi sürecinin işletmelerin IKY uygulamalarında değişiklik yapması ile Pandemi sürecinde çalışanların kariyer gelişimlerinin takip edilmesi arasında anlamlı ilişki vardır. ” hipotezi kabul edilmiştir.

Pandemi sürecinin işletmelerinin İKY uygulamalarında değişiklik yapması ile Pandemi sürecinde çalışanların motivasyon ve memnuniyetini artırıcı faaliyetler yapılması arasındaki ilişkiyi incelemek amacıyla Ki-Kare (Chi-Square - $\chi 2$ ) analizi gerçekleştirilmiştir. Elde edilen bulgular Tablo 14'te sunulmuştur.

Tablo: 14

\section{Pandemi Dönemi İKY ile Motivasyon}

\begin{tabular}{|c|c|c|c|c|c|c|c|c|}
\hline & & & & & & & & \\
\hline & & & Evet & Hayır & Iopram & $\chi^{2}$ & dt & $\mathrm{p}$ \\
\hline \multirow{4}{*}{ Pandemi Dönemi İKY } & \multirow{2}{*}{ Evet } & $\mathrm{f}$ & 97 & 103 & 200 & \multirow{6}{*}{13,045} & \multirow{6}{*}{1} & \multirow{6}{*}{,000 } \\
\hline & & $\%$ & 48,5 & 51,5 & 100,0 & & & \\
\hline & \multirow{2}{*}{ Hayır } & $\mathrm{f}$ & 7 & 33 & 40 & & & \\
\hline & & $\%$ & 17,5 & 82,5 & 100,0 & & & \\
\hline & \multirow{2}{*}{ Toplam } & $\mathrm{f}$ & 104 & 136 & 240 & & & \\
\hline & & $\%$ & 43,3 & 56,7 & 100,0 & & & \\
\hline
\end{tabular}

Pandemi sürecinin işletmelerin İKY uygulamalarında değişiklik yapması ile Pandemi sürecinde çalışanların motivasyon ve memnuniyetini artırıcı faaliyetler yapılması arasındaki ilişkiyi belirlemek amacıyla yapılan Chi-square $\left(\chi^{2}\right)$ testi bulguları iki değişken arasında istatistiksel olarak anlamlı bir ilişki olduğunu göstermiştir $\left(\chi^{2}=13,045 ; \mathrm{p}=0,000\right)$. Elde edilen bulgular neticesinde araştırmada ileri sürülen " $\mathrm{H}_{9}$ : Pandemi sürecinin işletmelerin IKY uygulamalarında değişiklik yapması ile Pandemi sürecinde çalışanların motivasyon ve memnuniyetini artırıc faaliyetler yapılması arasında anlamlı ilişki vardır." hipotezi kabul edilmiştir. 
Pandemi sürecinde işletmelerin çalışanların motivasyon ve memnuniyetini artırmak için yapmış oldukları faaliyetler ise Grafik 1'de görülmektedir. Pandemi sürecinde işletmelerin çalışanların motivasyon ve memnuniyetini artırmak için yapmış oldukları faaliyetler arasında; motivasyon konuşmacıları ile buluşma $(\% 56,5)$, hobi etkinlikleri $(\% 33,3)$ online psikolog desteği $(\% 26,9)$, online diyetisyen danışmanlık hizmeti $(\% 16,7)$, spor yapma etkinliği $(\% 14,8)$, yoga $(\% 12)$, konser $(\% 6,5)$, ikramiye gibi ek ödemeler $(\% 5,6)$ olduğu görülmektedir.

\section{Grafik: 1}

\section{Motivasyon Artırıcı Faaliyetler}

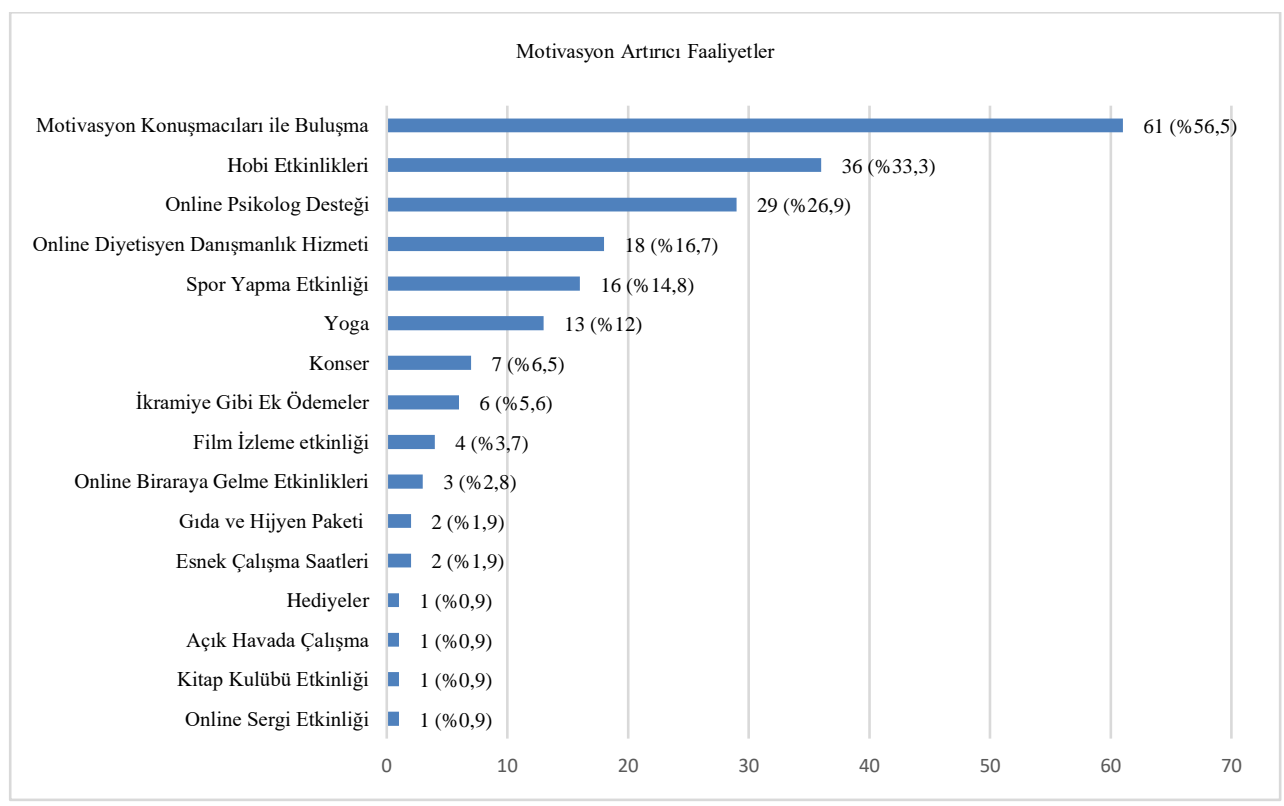

\section{Sonuç ve Değerlendirme}

COVID-19 Pandemisinin İKY'ye etkilerinin belirlenmesi amaciyla yapılan bu araştırmanın sonuçlarına göre; işletmelerin çalışan sayıları ile Pandemi sürecinde uzaktan veya esnek çalışma modeline geçmeleri arasında anlamlı bir ilişki olduğu belirlenmiştir. Çalışan sayısı fark etmeksizin Pandemi döneminde hem uzaktan hem de esnek çalışma modeli uygulandığı görülmektedir. İşletmelerin Pandeminin yoğun olduğu dönemlerde çoğunlukla uzaktan, pandeminin nispeten daha az yoğun olduğu dönemlerde ise esnek çalışma modelini tercih ettikleri görülmektedir. Bununla birlikte 250 ve üzeri sayıda çalışanı olan işletmeler diğer işletmelere göre daha yüksek oranda hem uzaktan hem de esnek çalışma modelini kullanmıştır. Campion vd. (2021: 3) çalışanların ortalama \%60'ının Mayıs-Haziran 2020'de evden çalışmaya geçtiğini, bu oranın Eylül ayı itibarıyla \%80'den fazla olduğunu ve birçok işletmenin hem uzaktan hem de işyerinden olacak şekilde karma 
bir çalışma modeli uyguladıklarını belirlemişlerdir. Campion vd. (2021: 3) göre çalışanların yarıdan fazlası evde çalışmayı tercih ederken, tüm çalışanlar evden çalışmayı tercih etmemektedir.

İşletmelerin çalışan tedarik ve seçimi uygulamalarında Pandemi öncesinde ve döneminde farklılık olup olmadığ 1 belirlenmeye çalışılmıştır. İlk olarak işletmelerin online iş başvurusu alıp almamaları değerlendirilmiştir. Işletmelerde Pandemiden önce online iş başvurusu alınması ile Pandemi döneminde online iş başvurusu alınması arasında anlamlı ilişki olmadiğg belirlenmiştir. İşletmelerin pandemiden önce de büyük çoğunluğunun online iş başvurusu aldıkları söylenebilir. İşletmelerin online başvuru alma işlemleri Pandemi döneminde artarak devam etmiştir. Pandemi döneminde işletmelerin çoğunlukla yeni çalışan istihdamı yoluna gitmedikleri söylenebilir. Haziran ayının ikinci haftasında yapılan bir ankete katılan özel sektör CEO'larının yüzde 59'u, işletmelerinin zararını azaltmak için ilk olarak işe alımları dondurduklarını belirtmişlerdir (Sines, 2020: 10). Bununla birlikte Pandemi döneminde yeni çalışan istihdamında bulunan işletmelerin çalışan tedarik ve seçim süreçlerinde bazı değişiklikler olmuştur.

İşletmelerde Pandemiden önce online mülakat yapılması ile Pandemi Döneminde online mülakat yapılması arasında anlamlı ilişki olduğu belirlenmiştir. Pandemi öncesi online mülakat yapanların büyük bir çoğunluğu Pandemi döneminde online mülakatların artmış olduğunu belirtmişlerdir. Pandemi döneminde işletmeler zorunlu olarak online mülakat yapmaya yönelmişlerdir.

İşletmelerde Pandemi sürecinden önce online genel yetenek testleri yapılması ile Pandemi döneminde online genel yetenek testleri yapılması arasında anlamlı ilişki olduğu belirlenmiştir. Pandemi döneminde işletmeler çalışan tedarikinde online genel yetenek testleri yapmaya yönelmişlerdir.

İşletmelerde Pandemiden önce online kişilik testleri yapılması ile Pandemi döneminde online kişilik testleri yapılması arasında anlamlı bir ilişki olduğu görülmüştür. Pandemi öncesi online kişilik testleri yapan işletmelerde \%45,6'sının pandemi döneminde online kişilik testleri yapılması artmışken \%51,1'inde bu yönde bir değişiklik olmadığ1 görülmektedir. Pandemi öncesi online kişilik testleri yapılmadığını belirten işletmelerin \%64,7'sinin Pandemi döneminde de bu uygulamalarında bir değişikliğe gitmedikleri görülmektedir. Dolayısıyla Pandemi döneminde işletmelerde çalışan tedarik ve seçiminde online kişilik testleri uygulanması artmıştır.

Pandemiden önce daha çok yüz yüze yapılan mülakatlar pandemi ile birlikte neredeyse tamamen online ortamlarda yapılmaya başlanmıştır. Aynı şekilde başvuruların alınması, kişilik ve yetenek testlerinin yapılmasında da online platformların kullanımı artmıştır. Bu konuda araştırmadan elde edilen bulgular ile diğer araştırma bulguları ve şirketlerin açıklamaları paralellik göstermektedir. Örneğin; Amazon, yüz yüze görüşmelerin çoğunu iptal ederek, adayların işe alım uzmanları ile bağlantı kurmaları, gerekli belgeleri doldurmaları ve şirketin video konferans yazılımı olan Amazon Chime aracılığıla 
röportajlara katılmaları için sanal görüşme portalları kurmuştur (Maurer, 2020). Ayrıca, Mercer'ın yapmış olduğu araştırma sonucuna göre; COVID-19 Pandemisi sürecinde işletmelerin \%59,9'unun işe alım süreçlerinin sanal/online olarak sürdürülmesi kararı aldıkları; işletmelerin \%32,3'ünün değerlendirme merkezi uygulamalarının online ortamda sürdürülmesi kararı aldıkları belirlenmiştir (Mercer, 2020). Pandemi döneminde işletmeler çalışan tedarik ve seçimi süreçlerini online ortama taşımak durumunda kalmışlardır.

COVID-19 Pandemisi İKY birimlerinin önemli uygulamalarından birisi olan eğitim konusunda da önemli etkilere neden olmuştur. İşletmelerin büyük çoğunluğu eğitimlerini online platformlara taşımışlardır. Pandemi sürecinin işletmelerin IKY uygulamalarında değişiklik yapması ile ĕgitim uygulamaları arasında anlamlı bir ilişki olduğu belirlenmiştir. Pandemi sürecinin işletmelerin İKY uygulamalarında değişiklik yaptığını belirtenlerin \%44,5'i Pandemi döneminde eğitimlerinin tamamen online verilmeye başlandiğ 1 belirtmişlerdir. Pandemi sürecinin işletmelerin İKY uygulamalarında değişiklik yapmadığını belirten işletmelerin ise \%55'nin Pandemi döneminde eğitim uygulamalarında da değişiklik olmadığını belirttikleri görülmektedir. Dolayısıyla bu grupta yer alan işletmelerin yarıdan fazlasının iş ve işlemlerini online ortama taşımakta zorlandıkları söylenebilir. Araştırmadan elde edilen sonuçlara paralel olarak, Mercer'ın yapmış olduğu araştırma sonucuna göre de COVID-19 Pandemisi sürecinde işletmelerin \%71,3'nün eğitimlerini sanal/online olarak sürdürme kararı aldıkları belirlenmiştir (Mercer, 2020).

COVID-19 pandemisinin işletmelerin ücret politikaları üzerindeki etkileri açısından incelendiğinde Pandemi sürecinin işletmelerinin İKY uygulamalarında değişiklik yapması ile ücret uygulamaları arasında anlamlı ilişki olmadığı görülmüştür. Pandemi sürecinin işletmelerin İKY uygulamalarında değişiklik yaptığını belirtenlerin \%74'ü, tüm katılımcıların ise \%73,8'i çalışanların ücretlerinde bir değişiklik olmadığını belirtmişlerdir. Yaşanan Pandemi nedeniyle işletmelerin ücret artışına gidemedikleri görülmektedir. Campion vd. göre (2021: 5), işletmeler maliyeti azaltma çabaları içine çalışanlara yapılan ödemeleri de eklemişlerdir. Campion vd. (2021: 5), işletmelerin yaklaşık yarısının, bazı çalışanlar için yükselme ve ikramiyeleri iptal ettikleri, erteledikleri veya dondurduklarını; üçte birinin ise bunları düşürdüklerini belirtmişlerdir.

İşletmeler hükümetler tarafından desteklenen “Kısa Çalışma Ödeneği”nden faydalanmışlardır. Bu ücret sisteminin amacı çalışanların işsiz kalmalarının önüne geçmek için maaşların bir kısmının devlet tarafından karşılanmasıdır. Bu sayede hem çalışanlar hem de işletmeler pandemi sürecinin olumsuz etkilerinden bir nebze de olsa kurtulabilmişlerdir. Pandemi döneminde çalışanların ücretlerinde değişiklik olup olmaması ile kısa çalışma ödeneğinden faydalanma arasında anlamlı ilişki olduğu görülmüştür. İşletmeler genel olarak çalışanlarının ücretlerinde artış yapamadıkları ya da çalışanların ücretlerini ödemek için kısa çalışma ödeneğinden faydalandıkları görülmektedir. Çalışanların ücreti arttı diyenlerin \%52,8'i, azaldı diyenlerin \%100'ü, değişmedi diyenlerin \%64,4'nün Kısa Çalışma Ödeneğinden faydalanmakta olduğu görülmektedir. 
İşletmelerin çalışan sayıları ile Pandemi sürecinde kısa çalışma ödeneğinden faydalanmaları arasında anlamlı ilişki olduğu görülmüştür. Çalışan sayısı 50-249 ile 250 ve üzeri olan işletmeler 1-49 arasında çalışanı olan işletmelere göre daha yüksek oranda Kısa Çalışma Ödeneğinden faydalanmaktadırlar. İşletmeler çalışan sayıları artıkça Pandemi döneminin olumsuz koşullarından kurtulmak için çalışan ücretlerinin bir kısmının devlet tarafından desteklenmesinden faydalanarak maliyetlerini düşürmek istemektedirler.

Yapılan araştırmada Pandemi sürecinin işletmelerin İKY uygulamalarında değişiklik yapması ile performans takip sistemleri arasında anlamlı ilişki olduğu görülmüştür. Pandemi sürecinin işletmelerin İKY uygulamalarında değişiklik yaptığını belirtenlerin \%70'i; Pandemi sürecinin işletmelerin IKY uygulamalarında değişiklik yapmadığını belirtenlerin ise \%95'nin performans takip sisteminde değişiklik olmadı̆̆ını belirtmişlerdir. Tüm katılımcıların sadece \%8,3 tamamen online hale getirildiğini belirtirken \%17,5'i kısmen online hale getirildiğini belirtmektedir. $\mathrm{Bu}$ sonuçlar paralelinde işletmelerin performans takip sistemlerini online ortama taşımakta zorlandıkları belirtilebilir. Ayrıca, dijital teknolojiler sayesinde performans takibi kolaylaşmakla birlikte çalışanların içinde bulunduğu olağanüstü durumdan dolayı performans beklentilerinde değişikliklere gidilmesi gerekebilmektedir. Mercer'ın yapmış olduğu araştırma sonucuna göre; işletmelerin \% 74,3'ü kurumsal iş hedefleri ile birlikte çalışanların yılsonu performans hedeflerinin revize dileceğini bildirmişlerdir (Mercer, 2020).

Pandemi sürecinin işletmelerin İKY uygulamalarında değişiklik yapması ile Pandemi sürecinde çalışanların kariyer gelişimlerinin takip edilmesi arasında anlamlı bir ilişki olduğu görülmüştür. Pandemi sürecinin işletmelerin İKY uygulamalarında değişiklik yaptığını belirtenlerin \%75'i çalışanlarının kariyer takibini yaptıklarını; Pandemi sürecinin işletmelerin İKY uygulamalarında değişiklik yapmadığını belirtenlerin ise \%55'inin çalışanlarının kariyer takibini yaptıklarını belirtmişlerdir. Pandeminin getirdiği olumsuz koşullara rağmen işletmelerin çalışanlarının kariyer gelişimlerine önem verdikleri görülmektedir. Pandemi sürecinde çalışanların online kurslardan faydalanarak yeteneklerini geliştirmeleri kariyerlerinde olumlu bir ilerleme sağlayabilecektir. Jones'a göre (2020: 3940) işletmeler Pandemi sürecini çalışanlarının ekipleri yönetme, yapay zekâ, makine öğrenimi, robotlarla çalışma, İKY analitiği ve İKY için güncellenmiş istihdam yönetmelikleri vb. konularında kurslar alarak geçirmelerini sağlamalıdır. Çünkü pandemiden sonra bu yeteneklere daha fazla ihtiyaç duyulacaktır.

Pandemi sürecinin işletmelerin İKY uygulamalarında değişiklik yapması ile Pandemi sürecinde çalışanların motivasyon ve memnuniyetini artırıcı faaliyetler yapılması arasında anlamlı ilişki olduğu görülmüştür. Pandemi sürecinin işletmelerin İKY uygulamalarında değişiklik yaptığını belirtenlerin yarıya yakını $(\% 48,5)$ çalışanlarına yönelik motivasyon ve memnuniyeti artırıcı faaliyetler yaptıklarını; Pandemi sürecinin işletmelerin İKY uygulamalarında değişiklik yapmadığını belirtenlerin ise sadece \%17,5'nin çalışanlarına yönelik motivasyon ve memnuniyeti artırıcı faaliyetler yaptıklarını belirtmişlerdir. Tüm katılımcılar açısından bir değerlendirme yapıldığında işletmelerin yarıdan azının $(\% 43,3)$ çalışanların motivasyon ve memnuniyetinin artırılmasına önem verdikleri görülmektedir. 
Çalışanların Pandemi sürecinde yaşamış olduğu olağanüstü koşullar göz önüne alındığında işletmelerin bu konuya daha fazla önem verip çalışanların moral ve motivasyonlarını artırmaya odaklanmaları gerekmektedir. Yapılan araştırmanın sonuçlarına göre; işletmelerin çalışanlarının motivasyon ve memnuniyetini artırmak için en çok Motivasyon konuşmacıları ile buluşma $(\% 56,5)$, hobi etkinlikleri $(\% 33,3)$, online psikolog desteği $(\% 26,9)$, online diyetisyen danışmanlık hizmeti $(\% 16,7)$, spor yapma etkinliği $(\% 14,8)$, yoga $(\% 12)$, konser $(\% 6,5)$, ikramiye gibi ek ödemeler $(\% 5,6)$ den faydalandıkları görülmektedir.

Yapılan araştırma sonuçlarına göre COVID-19 Pandemisi işletmelerin İKY uygulamaları üzerinde önemli değişikliklere yol açmıştır. İşletmeler Pandemi döneminde daha fazla online mülakat, genel yetenek ve kişilik testi yapmışlardır. İş başvuruları pandemiden önce de büyük oranda online olarak alınsa da Pandemi döneminde bu oran artarak devam etmiştir. İşletmelerin Pandemi döneminde eğitim uygulamalarını çoğunlukla online ortama taşıdıkları, aynı şekilde performans takip sistemlerini online olarak gerçekleştirmeye çalıştıkları görülmektedir. Ancak bu noktada işletmelerin dijitalleşmeye gerekli önemi vermedikleri ya da dijitalleşme alt yapılarının yetersiz olduğu söylenebilir. İKY uygulamalarının dijital ortama taşınması Pandemi sonrasında da işletmelerin etkinlik ve verimliliklerini artıracaktır. İşletmelerin Pandemi sürecinde çalışanlarının kariyer gelişimlerine önem vermeleri ve çalışanların kariyer takibini yapmaları oldukça önemli bir sonuç olarak görülmektedir. Çünkü bu süreçte çalışanların kariyerlerinin desteklenmesi Pandemi sonrasında hem çalışanlar hem de işletmeler için olumlu sonuçlar ortaya koyacaktır. Pandemi sürecinde çalışanların yaşamış olduğu en önemli sorunlar arasında uzaktan çalışmadan kaynaklı problemler, virüs bulaşması endişesi, psikolojik sorunlar vb. sayılabilir. Bu sorunlar ile başa çıkabilmek için işletmeler tarafından çalışanların moral ve motivasyonlarını artırıcı faaliyetler düzenlemesi oldukça önemlidir. Ancak bu konuda işletmelerin gerektiği kadar çaba sarf etmedikleri görülmektedir. İşletmelerin çalışanlarının moral ve motivasyonlarını artırıcı faaliyetler düzenlemesinin hem çalışılanlar hem de işletmeler için oldukça fazla olumlu geri dönüşleri olabilir. Dolayısıyla işletmeler bu konuya daha fazla önem vermelidirler.

Araştırmadan elde dilen bulguların hem işletmelere hem de literatüre anlamlı katkı sağlayacağı düşünülmektedir. Ancak araştırmadan elde edilen bulguların genellenebilirliği açısından bundan sonra yapılacak araştırmalarda daha çok katılımcı ile yapılması gerekmektedir.

\section{Kaynaklar}

Acar, Y. (2020), "Yeni Koronavirüs (Covid-19) Salgını ve Turizm Faaliyetlerine Etkisi”, Güncel Turizm Araştırmaları Dergisi, 4(1), 7-21.

Ahrendt, D. et al. (2020), Living, Working and COVID-19, COVID-19 Series, Publications Office of the European Union, Luxembourg.

Akbaş-Tuna, A. \& O. Çelen (2020), "İşletmelerin İnsan Kaynakları Yönetimi Uygulamaları Üzerinde Covid-19 Pandemisinin Etkileri”, OPUS-Uluslararası Toplum Araştırmaları Dergisi, 16(30), 2710-2759. 
Akbaş-Tuna, A. \& Z. Türkmendağ (2020), “Covid-19 Pandemi Döneminde Uzaktan Çalışma Uygulamaları ve Çalışma Motivasyonunu Etkileyen Faktörler”, İşletme Araştırmaları Dergisi, 12 (3), 3246-3260.

Akca, M. \& M. Tepe-Küçükoğlu (2020), "COVID-19 ve İş Yaşamına Etkileri: Evden Çalışma”, Journal of International Management, Educational and Economics Perspectives, 8(1), 71-81.

Akınc1, E. (2020), "Covid-19 Salgını Kapsamında Şirket Yöneticilerinin Almaları Gereken Önlemlere Genel Bir Bakış”, Istanbul Ticaret Üniversitesi Sosyal Bilimler Dergisi, 19(38), 202-223.

Aslan, R. (2020), “Tarihten Günümüze Epidemiler, Pandemiler ve Covid-19”, Ayrıntı Dergisi, 8(85), $35-41$.

Ateş, Z.G. (2020), “COVID-19’un İşverenin İş Sağlığı ve Güvenliği Konusunda Alması Gereken Önlemlere Etkisi”, İstanbul Ticaret Üniversitesi Sosyal Bilimler Dergisi, 19(38), 161179.

Aydın-Göktepe, E. (2020), "Kriz Döneminde İş Sürdürülebilirliğine Yönelik Yönetim Uygulamaları; Cavid-19 Pandemi Araştırmas1", Journal of Social, Humanities and Administrative Sciences, 6(26), 630-638.

Bozkurt, A. (2020), "Koronavirüs (Covid-19) Pandemi Süreci ve Pandemi Sonrası Dünyada Eğitime Yönelik Değerlendirmeler: Yeni Normal Ve Yeni Eğitim Paradigması", Açıköğretim Uygulamaları ve Araştırmaları Dergisi, 6(3), 112-142.

Caligiuri, P. vd. (2020), "International HRM Insights for Navigating the COVID-19 Pandemic: Implications for Future Research and Practice”, Journal of International Business Studies, 51, 697-713.

Campion, E.D. et al. (2021), "Technical Report: Impact of COVID-19 and Human Resource Management Agility Practices", The Industrial-Organizational Psychologist, 58(3), 1-7.

Carnevale, J.B. \& I. Hatak (2020), "Employee Adjustment and Well-Being in the Era of COVID-19: Implications for Human Resource Management", Journal of Business Research, 116, 183-187.

Chadee, D. et al. (2021), "Is Digital Technology the Magic Bullet for Performing Work at Home? Lessons Learned for Post COVID-19 Recovery in Hospitality Management", International Journal of Hospitality Management, 92, 1-8.

Deloitte (2020), COVID-19 Workforce Strategies for Post-COVID-Recovery, $<$ https://www2.deloitte.com/content/dam/Deloitte/us/Documents/aboutdeloitte/workforce-strategies-for-post-covid-19-recovery.pdf>, 14.01.2021.

Demir, M. vd. (2020), “Coronavirüs (Covid-19)'ün Türkiye'de Turizm Üzerindeki Öncüllerinin, Etkilerinin ve Sonuçlarının Değerlendirilmesi”, International Journal of Social Sciences and Education Research, 6(1), 80-107.

Dirani, K.M. et al. (2020), "Leadership Competencies and the Essential Role of Human Resource Development in Times of Crisis: a Response to Covid-19 Pandemic", Human Resource Development International, 23(4), 380-394.

Dönmez, İ. \& S. Gürbüz (2020), “Üniversite Öğrencilerinin Covid-19 Virüsü Hakkında Bilişsel Yapılarının Belirlenmesi”, Manas Sosyal Araştırmalar Dergisi, 9(4), 2159-2172.

Erdil, O. vd. (2004), “İnsan Kaynakları Uygulamalarıyla Örgütsel Performans Arasındaki İlişkileri Araştırmaya Yönelik Bir İnceleme”, DEÜ İIBF Dergisi, 19(2), 101-122. 
Hecklaua, F. et al. (2016), "Holistic Approach for Human Resource Management in Industry 4.0", Procedia CIRP, 54, 1-6.

ILO (2020), Teleworking During the COVID-19 Pandemic and Beyond: A Practical Guide, July, Geneva.

İlhan, Ü.D. (2020), “Covid-19 ile Mücadelede İnsan Kaynakları Yönetimi Uygulamalarında İhtiyaç Duyulan Aksiyonların Belirlenmesine Yönelik Örgütsel Müdahale Yöntemi Önerisi”, Gaziantep Üniversitesi Sosyal Bilimler Dergisi, 19, 288-307.

Jones, K. (2020), “HR in the Time of COVID-19”, Feature, 2nd Quarter, 38-40.

Kırpık, G. (2020), "COVID-19 Pandemisinin İnsan Kaynakları Üzerindeki Etkisinin Akademi, Medya ve İş Dünyası Perspektifinden İncelenmesi”, Manas Sosyal Araştırmalar Dergisi, 9(4), 2393-2406.

Kraus, S. et al. (2020), "The Economics of COVID-19: Initial Empirical Evidence on How Family Firms in Five European Countries Cope with the Corona Crisis", International Journal of Entrepreneurial Behavior \& Research, 26(5), 1067-1092.

Lloyd-Jones, B. (2021), "Developing Competencies for Emotional, Instrumental, and Informational Student Support During the COVID-19 Pandemic: A Human Relations/Human Resource Development Approach", Advances in Developing Human Resources, 23(1), 41-54.

Maurer, R. (2020), “Job Interviews go Virtual in Response to COVID-19”, Society for Human Resources Management, March 17.

Mercer (2020), Covid-19 Salgınının Türkiye’de Çalışma Hayatı Üzerine Etkileri Anketi, Nisan, <https://www.mercer.com.tr/rapor-makale-arastirma/nisan-covid19-anketi.html>, 14.01.2021.

Provino, J. (2020), "HR Should Not Waste the COVID-19 Crisis", HR Future May, 30-31.

Sayan, H. (2020), “COVID-19 Pandemisi Sürecinde Öğretim Elemanlarının Uzaktan Eğitime İlişkin Görüşlerinin Değerlendirilmesi”, AJIT-e: Bilişim Teknolojileri Online Dergisi, 11(42), 100-121.

Serinikli, N. (2021), "Covid 19 Salgın Sürecinde Örgütsel Değişim: Uzaktan/Evden Çalışma Modeli”, Firat Üniversitesi Sosyal Bilimler Dergisi, 31(1), 277-288.

Sines, D. (2020), "How Lean HR Teams Can Find Success Beyond COVID-19”, HR News Magazine, November, 10-11.

Şen, E. \& G.F. Batı (2020), "COVID-19 Pandemi Krizinin Yönetim ve Ekonomi Politik Üzerine Olası Etkileri”, Yönetim, Ekonomi ve Pazarlama Araştırmaları Dergisi, 4(2), 71-84.

Şener, İ. \& N. Abunasser (2020), "The Effect of Individual Antecedents on Work-Family Conflict: A Research on Employees Working from Home due to Covid-19 Pandemic", İs ve Insan Dergisi, 7(2), 189-201.

WHO (2020), WHO Director-General's opening remarks at the media briefing on COVID-19-11 March 2020, <https://www.who.int/director-general/speeches/detail/who-directorgeneral-s-opening-remarks-at-the-media-briefing-on-covid-19---11-march-2020>, 12.12.2020.

Yakut, E. vd. (2020), "Sağlık Personelinin Covid-19 Korkusu ile Tükenmişliği Arasındaki İlişkide Aşırı İş Yükü ve Algılanan Sosyal Desteğin Etkisinin Yapısal Eşitlik Modeliyle Belirlenmesi”, EKEV Akademi Dergisi, 24(83), 241-262. 
Kılıç-Kırılmaz, S. (2021), “COVID-19 Pandemisinin İnsan Kaynakları Yönetimi Üzerine Etkilerinin Belirlenmesine Yönelik Bir Araştırma”, Sosyoekonomi, 29(50), 255-276.

Yılmaz, B. (2020), "COVID-19 Pandemi Sürecinin Çalışanlar Üzerine Etkisi: Kamu Sektöründe Çalışanlar Üzerine Uygulamalı Bir Araştırma”, Üçüncü Sektör Sosyal Ekonomi Dergisi, 55(3), 724-1740. 